\title{
Re-evaluating the Question of Standardization of Nigerian English*
}

\author{
Emeka C. Ifesieh \\ Delta State University, Abraka, Delta State, Nigeria
}

\begin{abstract}
It is difficult to deny the existence of Nigerian English, just as it is difficult to deny the existence of British English and American English. This claim arises from the fact that what characterizes a people's linguistic norm takes its rise from the totality of the people's sociocultural practices of which meaningful verbal sounds are of great essence. The meaningful verbal sounds serve as the chief instrument for communicating meanings, feelings, ideas, and abstractions. Whereas the existence of Nigerian English is no doubt, what constitutes its standard variety has been under contestation. In this write up, argument on standardization of Nigerian English is built-up on the basis of the various stages which the language has passed through and is still passing through in Nigeria. Argumentatively, standard variety of Nigerian English is identified and examined with the aim of demonstrating how efforts in standardizing it are made through empirically reliable criteria.
\end{abstract}

Keywords: Nigerian English, contestation of the standard variety, standardization, argumentatively empirically reliable criteria

\section{Introduction}

English language was introduced into Nigeria with the coming of the Europeans around the 16th century (Awonusi, 2004, p. 67). First, it was the language of trade along the coastal areas. At the coast, it came in contact with local languages. The contact gave rise to Nigerian Pidgin (NP). Subsequently, with the coming of the colonialists and the missionaries, the language was implanted fully in the country via the educational ordinance of 1882, which made it the language of instruction in schools. Over the years, the language gained acceptance in the country and assumed functions in different domains of the society. As the first official language in the country, it is used virtually in all domains sociopolitical and economic actions, e.g., in official businesses, in the legislature, in all the government offices, and in the administration of education. It is also used in non-governmental domains such as in commerce and in journalism, also in literature and in most informal gatherings. It also serves as a restricted lingua franca.

In consideration of the facts above, it is appropriate to mention that English has displaced most indigenous languages by assuming functions hitherto performed by them. Invariably, it undergoes cultural adaptation and hybridity (Wolf \& Igboanusi, 2006). Arguably, English is no longer foreign to Nigeria. It is often considered as a

\footnotetext{
* This article is an improvement on the original (on standardization of Nigerian English) written by the author and published in Awka Journal of Languages and Linguistics, Vol. 2, 2006, pp. 61-70.

Emeka C. Ifesieh, senior lecturer, Ph.D., Department of Languages and Linguistics, Delta State University.
} 
near mother tongue in Nigerian linguistic ecology. Nevertheless, it is a fact that in Nigeria currently many primary, secondary, and university students speak English as their mother tongue. They lack both competence and performance in the indigenous languages. Multilingualism plays a major role here: On account of Nigeria's multiethnic and multilingual nature, English language is seen as a neutral language to promote national and ethnic cohesion, thereby giving it power and prestige. However, due to appeal to tradition and prejudice, English is seen as a second language in the Nigerian language situation, even though it now carries the load of the indigenous tongues in terms of its use in virtually all domains. According to Akindele and Adegibite (1999) "a second language is a variety in which a bi/multilingual person conducts his everyday activities but shares this role with another language in which the speaker has greater linguistic facility or intuitive knowledge" (p. 51).

Of interest is the word "bi/multilingual" in the Akindele and Adegbite's definition of a second language: It calls to mind the reality of varieties of Nigerian English. Basically, the concept of variety of Nigerian English is associated with transfer of features of the languages of Nigerian learners of English to the target language, English. Akindele and Adegbite's definition of a second language tacitly confirms the assertion that a person who is neither a bi- nor a multilingual has no second language. Therefore, what the person speaks constitutes his first and only language. Although the person's first language may be neither indigenous nor native, it can count as the person's mother tongue as long as it functions as the person's natural instrument of thought and communication as evident among a great preponderance of Nigerian youths and children who grew up with only one language-English.

Language is embedded in the culture of a people, which in turn encompasses their total world view. The peculiar multicultural nature of Nigeria necessitates a skewing of the language according to the particular needs of the people. It is in recognition of this fact that Jowitt (1991) states that an obviously attractive parameter for determining varieties within Nigerian English is the ethnic criterion (p. 38). lgboanusi (2002) recapitulates: "ethnic dialects of Nigerian English are determined by way of associating particular phonological, lexical, syntactic or semantic usage with particular ethnic groups" (p. 33). In the light of the above, it is evident that what would characterize a standard Nigerian English would take its rise from the varieties of Nigerian English. In view of this, the varieties of Nigeria English will be investigated briefly.

\section{Nigerian English and the Quest for Identification of a Standard Variety}

Varieties portend assortment. In relation to Nigerian English, varieties point to the different linguistic norms that impact on English in Nigeria and thereby give it variable colourations. According to Egwuogu (2004),

Varieties of Nigerian English arise from the interaction of English language with the local languages and from the different ways speakers of a second language try to approximate the sounds of the language. It also occurs as a result of interference from the mother tongue (MT). Interference occurs at phonological, grammatical and semantic levels; even at the level of lexis, interference can still be noticed. (p. 103)

A re-examination of Egwuogu's view would indicate three criteria for evaluating varieties of Nigerian English, viz: internal criterion, which refers to phonological, syntactic, and semantic structures of a variety of speech; functional criterion, which refers to the use to which the society makes of a variety of speech; and attitudinal criterion, which refers to the idea that a variety of speech may be perceived as unique to a particular speech community. Putting these criteria into consideration and using ethnic, educational, and linguistic 
parameters, scholars have identified different varieties of Nigerian English. According to Brosnahan (1958), four varieties of Nigerian English exist:

Pidgin, which is used by people with no formal education.

The variety used by those with only primary education.

The variety used by those with secondary education.

The variety used by those with university education. (pp. 97-110)

At the time Brosnahan stipulated the four varieties certain higher institutions that award degrees like the NCE (National Certificate of Education), OND (Ordinary National Diploma), and HND (Higher National Diploma) were not existent in Nigeria. Institutes, technical colleges and TTC II (Teachers' Training College) were also in the same category, thereby giving credence to this claim. Essentially, it can be pointed out that despite the considerable development one may claim that NP has attained, it has not lost its congenital nature: in terms of aspects and tense formations, NP resembles African tone languages. NP also uses tone variations to distinguish between interrogatives and indicative statements. The point being pursued here is that NP ought not to have been described as a variety of Nigerian English. As a point of fact NP has its own varieties, e.g., Warri Pidgin is different from Port-Harcourt one, which in turn is different from the one spoken in Lagos.

Banjo $(1971,1996)$ is of the view that the choice of an appropriate model for identifying varieties should be based on the two criteria of social acceptability and international intelligibility on the assumption that such a model given the second language situation should have a high prestige at home and substantial intelligibility abroad. Subsequently, Banjo (1996) stipulates the following varieties:

\footnotetext{
Variety I: Nigerians who have picked up the language as a result of the exigencies of their occupation. Much of it can be described as "broken English".

Variety II: The speech exhibits signs of systematic learning of English and its speakers are likely to have had at least primary education. Others may have had some secondary education as well and it represents the speech of most Nigerian bilingual speakers of English.

Variety III: This is the product of an even greater exposure to a standard variety of the language and represents a standard use of English in Nigeria. In most cases the exposure is obtained through education.

Variety IV: This includes Afro-Saxon to whom English is mother tongue. (pp. 75-80)
}

This diatypic (cf. Enkvist, Spencer, \& Gregory, 1964) classification of varieties of Nigerian English was described by Jowitt (1991) as arbitrary. However, despite its arbitrariness it is objective, empirical, and consistent. Bamgbose, Banjo, and Thomas (1995) also agree with Banjo (1971, 1993).

The concord stems from a common sense observation that variety III would ensure a standard which is both socially acceptable and maximally internationally intelligible, because speakers of variety III do so with minimal violation of the grammatical rules of English.

The relationship of all this to the previous discussion is obvious. The speakers of Nigerian English can then be defined more closely. It is however important to mention that standardization is not meant to fix the language once and for all in Nigeria, if anything, one chief character of a language is that it is dynamic. Secondly, the standard variety is not expected to be a rigid prototype but rather a cluster of diatypic varieties it will accommodate in informal register, for example slang, which is transient in nature, which may initially exist colloquially before it becomes a written form. In consonance with the immediate previous statement, Nigerian English encourages creativity. 
It has been established that there is what is accepted as a standard Nigerian English. However, the point is further substantiated hereunder by investigating the concept of standardization and finally correlating it with the question of standardization of Nigerian English.

\section{The Concept of Standardization and the Question of Standardization of Nigerian English}

Brookes (2003) defines standard as "an established or accepted model; a criterion; a definite level of excellence or adequacy required" (p. 1476). In other words, it is a measure to which others must conform. In the classification of language varieties, the standard variety is usually delineated since it is the reference point for other varieties within a speech community. Ekong (1987) views standardization as a connected series of actions relating to codification and acceptance of a set of norms which define the right usage in a particular language group. One deduces from the above definition that the chief character of a standardized language is a document of laid down principles and rules guiding lexical (which includes orthography), phonological, and semantic combinations in a language. The issue of acceptance presupposes intelligibility because no one is likely to accept a language one does not understand as a means of communication. So acceptance should be understood extensively as both intra- and international acceptance and intelligibility. To further underpin the thrust of the above definition, Akindele and Adegbite (1999) state:

The standard dialect is that variety associated with formal education and manifested in the speech and writing of educated elites. The variety is accorded social prestige because of its propensity to civilization and its wider acceptability by all speakers of the language. (p. 136)

Haugan (1959) points out some features to be put into consideration in language standardization: selection of norms, codification of forms, elaboration of functions, and acceptance by community (pp. 8-21). However, Akindele and Adegbite (1999) provide the view that in standardizing a language, the selection of features from a number of sub-varieties is inevitable (p. 136). Among the various dialects, a standard dialect emerges, usually via a historical accident, rather than via selection or legislation. This explication seems to indicate that Banjo's variety III, the product of greater exposure to a standard use of English in Nigeria does not take its rise from any dialect in Nigerian history.

Nevertheless, it can be said that Banjo takes into consideration that the speakers of variety III (predominantly people with higher institution exposure, e.g., university exposure) cut across the six geopolitical zones of the country and that at that level of linguistic exposure dialectal interference would have reduced to a point where it does not blur intra- and international intelligibility. Jubril $(1982,1986)$ provides a linguistic evidence for many statements that have been made. In his investigation, he provides justification for recognizing two broad diatopic sub-varieties, namely Hausa and Southern. Within each diatopic sub-variety, he recognizes on the basis of distance from or proximity to Standard British basic and sophisticated sub-varieties, which appear to be equivalent to Banjo's varieties II and III. He observes a growing convergence between Basic Hausa and Basic Southern. Therefore, he suggests a fifth category, a Southern-influenced Hausa variety which he predicts may be the forerunner of a more homogenous Nigerian accent.

From what has been written above, it is evident that the question of standardizing Nigerian English is not new and that efforts are being made to delineate what a standard variety is from what it is not. For example, there are dictionaries of Nigerian English (cf. Igboanusi, 2010; Blench, 2005). Sequel to that, a recognized standard 
variety must be codified. There must be a codification of the phonological and grammatical rules. Similarly, there must be dictionaries of the language coded in the standard variety. All codified documents will remain as points of reference and also serve the purpose of correcting errors. As regards codification, more work has been done in characterizing lexical and semantic indexical markers of standard Nigerian English than in syntactic and phonological markers. For instance, Bamgbose (1971) draws attention to the semantic changes that have taken place in some varieties of Nigerian English in such words as "themselves", "globe", "to take in", "a been to" (pp. 43-44). According to Banjo (1995),

It appears to be generally recognized that it is in the lexical, semantic areas together with distinctive idiomatic expressions that Nigerian English is likely to make a real contribution to the development of the English Language worldwide, and so research has been intensified in this area, not only in thesis and dissertations, but also in publications. (p. 214)

To further underpin this point, Igboanusi (2002), shows how English is nativized by Nigerian literary writers, which is a great contribution to Nigerian English and the language in general. Odumuh (1984) provides a very thorough inquiry into the syntactic and lexical properties of the Nigerian English (pp. 155-228). He discusses a large number of lexical items and expressions which have undergone semantic change in Nigerian usage and compares them with usage in British Standard English (BSE) a few examples are:

Table 1

Some BSE and Nigerian English Words

\begin{tabular}{ll}
\hline BSE & Nigerian English \\
\hline Academic & Academician \\
Wealthy woman & Cash madam \\
Traffic snarl-up & Go slow \\
Undue influence & Long leg \\
\hline
\end{tabular}

In the area of syntax a lot of work has equally been done by various authors such as Tomori (1967), Odumu (1981), Kujore (1985), and Jowitt (1991). Jowitt, it appears, is more systematic in this regard. His categorization can be regarded as typical and is briefly summarized below:

(1) Classification: This deals with form-class shift. E.g., "he offed the light", which must be variety I or variety II, but not variety III ("off" belongs to the class of words called affix, but in the example clause above, it is treated as a verb. Such usage indicates a shift from its normal application to another);

(2) The number system: This concerns the pluralisation of such SBE uncountable nouns as "advice", "equipment" (These words, incidentally are also pluralised in American English) junk' and personnel';

(3) Inflections: examples: "he used to drink too much" instead of "he drinks too much" or "he use to drink too much", "did she wanted him?" instead of "did she want him?" (This must belong to the lowest brands of variety I);

(4) Sub-categorization of verbs: SBE stative verbs "hear", "smell”, used as event verbs in Nigerian English;

(5) The use of prepositions generally;

(6) Modals: examples: Nigerian English: "after the referee might have arrived, the match will begin" for SBE "after the referee has arrived...";

(7) The wide spread use, even in some variety III usage, of the reflexive "themselves", where SBE would use the reciprocals "each other" or "one another"; 
(8) Relativization: examples: Nigerian English—-"I know the person who his father has died". For SBE, "I know the person whose father has died".

These syntactic anomalies in Nigerian English call to mind the concept of common core features in English. According to Quirk, Greenbaum, Leech, and Svartvik (1972), the concept of Englishness consists in a common core or nucleus, which can be termed "English" (p. 13). It is essentially the common core features of English that impact a high degree of uniformity on the various varieties of world "Englishes" so that they are mutually intelligible despite the phonological, lexical, and grammatical differences that may exist among them. What Quirk's common core features portend for the standardization and particularly codification of Nigerian English is that the standard Nigerian English should be free from all errors of grammar, pronunciation, spelling, and punctuation. According to Quirk (1962), some common core features of English include the conventions of English orthography, the grammar of English and the English vocabulary, which are presented in the lexicon of the language (p. 99).

Consequently, all standard varieties of English are expected to obey the general rules of English grammar. However, it should be mentioned that since the greatest influence on English in Nigeria is the sociocultural context in which it is used, the influences of indigenous languages on English should be seen as possible signs of healthy adaptation and hybridity and of the creative capability and ingenuity that is normally associated with mother tongue learning and use. Thus lgboanusi (2002) states "nativisation is a common feature of all institutionalized second language varieties of English" (p. 35). The point under pursuit here is that while it is agreable that the common core features of SBE should be the pillars upon which Nigerian English is built, Nigerian English ought to retain its local colour, which of course is its major identity.

In the realm of pragmatics, a lot of research has equally been conducted and documented. Bamgbose (1971) draws attention to the use of words such as "sorry" and "well done" as phatic communion (p. 44), but in SBE, they have different situational and semantic applications. Adetugbo (1979a, 1979b) provides further examples in relation to deployment of structure and lexis of Nigerian English and SBE or American English (AE). Akere (1984) discusses the sociological determinants of the indigenization of the English language in Nigeria. In all these works, the lexis is a common feature of the SBE, but the senses in which it is used are definite indexical markers of non-standard usage. According to Banjo (1995), "there is a great scope for further divergence between Nigerian English and British English (BE) or American English (AE) in this respect, whereas in lexis, the sociocultural environment put an indelible stamp on the language" (p. 28). Chinua Achebe's use of semantic translation in his novels is a typical example. That is, some common core features may assume semantic expansion/extension in Nigerian English.

In the realm of phonology, researches have equally been carried out and documented. Prominent among them are the ones of Jubril (1982) and Adetugbo (2004, pp. 179-197). Adetugbo delineates the phonological problems of standardization of Nigerian English and subcategorized them in this manner: Vocalism, Consonantism, Syllable Structure, Stress, and Intonation. The bottom line of phonological problems in standardizing Nigerian English bears on the phonologically delimited dialects of Nigerian English. However, while interference appears as phonologically significant in Nigerian English, it is admissible that the feature yields to the establishment of a standard. 


\section{Summary, Conclusion, and Recommendation}

The history of English language in Nigeria has been concisely recounted. The views of various authors on varieties of Nigerian English as regards what ought to be the standard Nigerian English have also been weighed. Therefore, the popular view, Banjo's view has been adopted. Through a careful evaluation of the issues involved, it is observed that Nigerian English is on course for standardization.

English has become, per excellence, the language of international politics and diplomacy. It is also the language through which the globalization ideology is propelled. Currently, nations of the world are imbibing the global ideology. Subsequently, globalization and industrialization spread on the wings of technologization, which has ushered in new global template-democratization, for social re-engineering, re-evaluation, and re-conceptualization of happenings in human culture and history (cf. Ifesieh, 2015). Essentially, English plays a key role in the technologization. As instances: English is an official language in countries in which nearly "sixty percent (60\%) of African population live" (Phillipson, 1992, p. 27). Then, eighty percent (80\%) of the global information infrastructure is in English, "less than three percent (3\%) is from Africa and most of the less than $03 \%$ is in English" (Adegbola, 2006, p. 7). It is quite clear that English has tremendous powers.

Sequel to that, standardization of Nigerian English, its mastery and thorough appropriation in Nigeria in all spheres of life will serve as a strong impulse capable of galvanizing the multiethnic groups in the country into a quantum unit. However, in the socio-political realm, the multiethnic groups should be given acceptable and adequate sense of belonging in Nigeria. Otherwise, the feeling of loss of "will to meaning" will spring up within the affected ethnic groups irrespective of efficient language policy. The feeling of a total and ultimate meaninglessness of an ethnic group's life may lead to a certain type of neurosis among the group members for which logotherapy has coined a term, noögenic neurosis, i.e., a neurosis whose origin is a spiritual problem, a moral conflict or existential vacuum (cf. Frank1, 1967, p. 67). Said differently, the striving to find a meaning in life is the basic motivational force in man. Therefore, once that striving to find a meaning is blocked, the "will to meaning" becomes frustrated. Consequently, the noögenic neurosis sets in. Under such a circumstance, pursuit of a common national goal such as language policy implementation may not hold any significant sway.

A group of people sharing a common territory, characterised by sociocultural criteria of symbols: language, value system, and normative behaviour will certainly share more or less the same "will to meaning". Subsequently, if that "will to meaning" is perceived as lost by such a group, then lethal consequences follow: the existential vacuum can lead to "cognitive malfunction" and "blocked (group) growth" which ultimately cause the group members to display abnormal behavioural traits (Huffman, 2007, p. 502). Practically, the Odua People's Congress (OPC) a Yoruba ethnic militia in Nigeria went on wild rampage during President Olusegun Obasanjo's regime. They felt that the growth of the Yoruba ethnic group has been fettered by the prolonged rulership of the Hausa northern Nigerian oligarchy. Therefore, the group saw their brother's regime, Obasanjo's (i.e., 1999-2007) as the most appropriate moment for cessation. Incidentally, it was forcefully quelled. In 2015, with the re-emergence of the former Nigerian military dictator, General Muhamadu Buhari as the Nigerian democratically elected President, a movement from south-eastern Igbo ethnic group in Nigeria, Movement for the Actualization of the Sovereign State of Biafra (MASSOP) and a few similar groups felt marginalized and repressed in the state of affairs of the Federal Republic, due to age long marginalization and lack of adequate representation at the 
centre. Therefore, the group, whose pre-occupation has been trading, abandoned the business and began a regional demonstration in the whole south eastern states in addition to many south-south states of Nigeria where Igbo people live in their numbers. The objective has been the actualization of the sovereign state of Biafra. Also, the Muslim dominated north eastern states felt socio-politically and culturally suppressed by the Nigerian democratic experimentation. To many of them, their essence of being, moslem was in total peril. Consequently, a jihadist sect, Boko Haram sprang up among them and engaged in unalloyed sucidality, carnage, kidnapping, and wanton destruction of both human and material resources with the intention to create an Islamic state. It is obvious from the preceding statements that there is a definite need to galvanize the country into a socio-political and economic entity, in which all the multiethnic groups therein have a "will to meaning".

Having done that, more efforts should be made towards improving on the works already done. For example, dictionaries of Nigerian English should have phonetic transcriptions of words in addition to the word meanings and their applications. Secondly, there should be grammar books for Nigerian English which base their explanations on the common core features of the British English. Essentially, the government of the Federal Republic of Nigeria should encourage Nigerian English language development through efficient language policy implementation, conferences, seminars, grants, and scholarships.

\section{References}

Adegbola, T. (2006). Globalization: Colonizing the space flows. In F. Egbokhare and C. Kolawole (Eds.), Globalisation and the future of Nigerian languages (pp. 2-11). Ibadan: Ibadan Cultural Studies Group.

Adetugbo, A. (1979a). Nigerian English and communicative competence. In E. Ubahakwe (Ed.), Varieties and functions of the English language in Nigeria. Ibadan: African University Press.

Adetugbo, A. (1979b). Appropriateness and Nigerian English. In E. Ubahakwe (Ed.), Varieties and functions of the English language in Nigeria. Ibadan: African University Press.

Adetugbo, A. (2004). Problems of standardization in Nigerian English phonology. In A. B. K. Dadzie and S. Awonusi (Eds), Nigerian English: Influences and characteristics. Palmgrove, Lagos: Concept Publications.

Akere, F. (1984). A sociolinguistic model for communicative use of English. In R. Freeman and M. Jibril (Ed.), English language studies in Nigerian higher education. London: British Council.

Akindele, F., \& Adegbite, W. (1999). The sociology and politics of English in Nigerian: An introduction. Ile-Ife: Obafemi Awolowo University Press.

Awonusi, V. O. (2004). The functions of Nigerian English in relation to other Nigerian languages. In A. B. K. Dadzie and S. Awonusi (Eds), Nigerian English: Influences and characteristics. Palmgrove, Lagos: Concept Publications.

Bamgbose, A. (1971). The English language in Nigeria. In J. Spencer (Ed.), The English language in West Africa (pp. 35-48). London: Longman.

Bamgbose, A., Banjo, A., \& Thomas, A. (Eds.). (1995). New Englishes: A West African perspective. Bodija, Ibadan: Mosuro.

Banjo, A. (1971). Towards a definition of standard Nigerian spoken English. In Actes du 8e Congress de la Societe Linguistique de l'Afrique Occidentale (Proceedings of the 8th Congress of the West African Linguistics Association) (pp. 165-175). Abidjan: University of Abidjan.

Banjo, A. (1993). An endonormative model for the teaching of the English language in Nigeria. International Journal of Applied Linguistics, 3(2), 261-275.

Banjo, A. (1995). On codifying Nigerian English: Research so far. In A. Bamgbose, A. Banjo, and A. Thomas (Eds.), New Englishes. Ibadan: Mosuro.

Banjo, A. (1996). Making a virtue of necessity: An overview of the English language. Ibadan: University of lbadan Press.

Blench, R. (2005). A dictionary of Nigerian English. Cambridge: Mallam Dendo.

Brookers, I. (Ed.). (2003). The chambers dictionary. Edinburgh: Chambers Harrap Publishers.

Brosnaham, L. F. (1958). English in southern Nigeria. English Studies, 39, 97-110. 
Egwuogu, C. B. (2004). Nigerian English and varieties differentiation: A critical appraisal. In L. Oyeleye (Ed.), Language and discourse in society. lbadan: Hope publications.

Ekong, P. H. (1987). Nigerian teachers' perception of the acceptance of variety of the Nigerian spoken English (Unpublished Ph.D. thesis, University of Ibadan).

Enkvist, N., Spencer, J., \& Gregory, M. (1964). Linguistics and style. London: Oxford University Press.

Frankl, V. E. (1967). Psychotherapy and existentialism: Selected papers on logotherapy. New York: Aclarion Book.

Haugan, E. (1959). Planning for a standard language in modern Norway. Anthropological Linguistics, 1(3), 8-21.

Huffman, K. (2007). Psychology in action (8th ed.). Hoboken, USA: John Wiley and Sons.

Ifesieh, E. C. (2015). Challenges of semantic extensions of jihad power symbols vis-à-vis Boko Haram. European Journal of Language Studies, 2(1), 42-55.

Igboanusi, H. (2002). Igbo English in the Nigerian novel. Ibadan: Enicrownfit Publishers.

Igboanusi, H. (2010). A dictionary of Nigerian English (2nd ed.). Berlin: LIT Verlag.

Jibril, M. (1982). Phonological variation in Nigerian English (Unpublished Ph.D. thesis, University of Lancaster).

Jibril, M. (1986). Sociolinguistic variation in English. English World Wide, 7, 47-75.

Jowitt, D. (1991). Nigerian English usage: An introduction. Ikeja: Longman Nigeria.

Kujore, O. (1985). English usage: Some notable Nigeria variations. Ibadan: Evans.

Odumu, A. E. (1981). Aspects of the semantics and syntax of educated Nigerian English (Ph.D. thesis, Ahmadu Bello University).

Odumu, A. E. (1984). Educated Nigerian English as a model of standard Nigerian English. World Language English, 3(4), 231-235.

Phillipson, R. (1992). Linguistic imperialism. Oxford: Oxford University Press.

Quirk, R. (1962). The use of English. London: Longman.

Quirk, R., Greenbaum, S., Leech, G., \& Svartvik, J. (1972). A grammar of contemporary English. London: Longman.

Tomori, S. H. O. (1967). A study in the syntactic structures of the written English of pupils (Ph. D. thesis, University of London).

Wolf, H. G., \& Igboanusi, H. (2006). Empowerment through English-A realistic view of the educational promotion of English in post-colonial contexts: The case of Nigeria. In M. Puetz, J. Fishman, and J. N. Aertselaer (Eds.), Along the routes to power explanations of empowerment through language. Berlin: Mouton de Gryter. 